\title{
Seasonal variability of metabolically active bacterioplankton in the euphotic zone of a hypertrophic lake
}

\author{
Ruben Sommaruga ${ }^{1, *}$, Daniel Conde ${ }^{2}$ \\ ${ }^{1}$ University of Innsbruck, Institute of Zoology and Limnology, Technikerstr. 25, A-6020 Innsbruck, Austria \\ ${ }^{2}$ Facultad de Ciencias, Departmento de Limnología, Tristán Narvaja 1674, 11200 Montevideo, Uruguay
}

\begin{abstract}
We studied the seasonal variation in the abundance of metabolically active bacteria (cells with an active electron transport system based on the INT-reduction method) and the proportion of active cells in the euphotic zone of a hypertrophic lake with the objective of determining the main factors related to their dynamics. The annual average proportion of active cells was $-47 \%$ and changed from $-17 \%$ in winter to $100 \%$ in autumn. Both total direct counts (range: 1.5 to $20.4 \times 10^{6} \mathrm{ml}^{-1}$ ) and abundance of active cells (range: 0.4 to $6.0 \times 10^{6} \mathrm{ml}^{-1}$ ) varied annually by 14 -fold and were highly correlated $(\mathrm{r}=0.74, p<0.001)$. Bacterial activity, based on $\left[{ }^{14} \mathrm{C}\right]$-leucine uptake, was more strongly correlated with active bacterial abundance $(r=0.83, p<0.001)$ than with total bacterial counts $(r=0.70, p<$ 0.001 ). Water temperature explained $\sim 81 \%$ of the temporal variability of active bacterial abundance

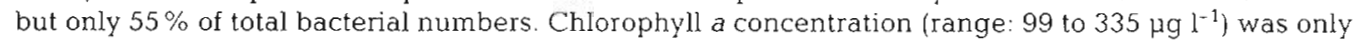
weakly correlated to the abundance of active bacteria $(\mathrm{r}=0.34, \mathrm{p}<0.05)$. Compared with data from other freshwater systems, our results show that although in this lake the average proportion of active bacteria was higher, their absolute abundance was lower than in less enriched systems.
\end{abstract}

KEY WORDS: INT method Bacterial activity $\cdot$ Temperature $\cdot$ Bacterivory $\cdot$ Cell-specific activity Lakes

\section{INTRODUCTION}

Heterotrophic bacteria play a dual role in aquatic ecosystems as decomposers of organic matter and as a food source for many organisms. It is generally accepted, however, that within the bacterial assemblage there are 2 fractions, represented by metabolically inactive and active cells (Stevenson 1978, Dufour et al. 1990, Gasol et al. 1995). Unfortunately, the recognition of these 2 fractions has attracted little attention in ecological studies, probably as a consequence of methodological difficulties. Therefore, our understanding of bacteria-mediated processes on a cell-specific basis has been hampered and still remains a crucial problem in aquatic microbial ecology.

Over the past $20 \mathrm{yr}$, several methods have been developed to estimate the fraction of active bacteria in aquatic environments. Among them, those involving

\footnotetext{
•E-mail: ruben.sommaruga@uibk.ac.at
}

microscopy (Zimmermann et al. 1978, Kogure et al. 1979, Tabor \& Neihof 1982a, Rodriguez et al. 1992) and, more recently, flow cytometry (Porter et al. 1995) have been preferred to the more laborious microautoradiography (Meyer-Reil 1978, Tabor \& Neihof $1982 \mathrm{~b})$. Although at present there is no standard method, the largest available data set is based on determinations of the activity of the electron transport system, predominantly by the use of the tetrazolium salt INT (Zimmermann et al. 1978) and, more recently, a fluorochrome version, CTC (Rodriguez et al. 1992). These 2 methods provide a less subjective determination of active bacteria when compared, for example, with direct viable counts using nalidixic acid (Kogure et al. 1979) and do not need additional substrates (Dufour \& Colon 1992).

Although few studies have analyzed in detail the variability of the abundance and proportion of active bacteria on a seasonal basis, the general picture is that despite the different methods used, in most aquatic 
systems only a small fraction is metabolically active. Dufour et al. (1990) suggested that in more productive systems the abundance and proportion of active bacteria may increase. Del Giorgio \& Scarborough (1995) have shown that the abundance of active cells as determined by the CTC method changed along the trophic gradient of several lakes in a similar way to total bacterial abundance (Bird \& Kalff 1984, Cole et al. 1988). Data from the literature compiled by del Giorgio \& Scarborough (1995) also indicated that the proportion of active cells increased from $<5 \%$ in ultraoligotrophic open-ocean areas to $>50 \%$ in highly productive estuaries with a mean value of $23 \%$ for lakes ranging from oligotrophic to eutrophic state. The situation, however, in highly enriched lakes is largely unknown because the microbiai ecology of hypertrophic systems has rarely been studied (Sommaruga \& Robarts in press).

In this study we analyzed on a weekly to biweekly sampling basis the seasonal variability of metabolically active bacteria in the euphotic zone of a hypertrophic lake and identified the main variables controlling their abundance. Active bacteria were determined by electron transport system activity assays, based on the reduction of the tetrazolium salt INT.

\section{MATERIALS AND METHODS}

Study area and sampling. Lake Rodó is a small (area $=1.3$ haj warm polymictic man-made system situated in the southern part of Uruguay $\left(34^{\circ} 55^{\prime} \mathrm{S}, 56^{\circ} 10^{\prime} \mathrm{W}\right.$ ). The lake is continuously dominated by filamentous cyanobacteria, mainly Planktothrix (Oscillatoria) agardhii, because of its shallowness $(1.1 \mathrm{~m})$, high nutrient load (annual mean concentration of total phosphorus and nitrogen $=430$ and $2900 \mathrm{\mu g} \mathrm{l}^{-1}$, respectively), low flushing rate and strong mixing. Accordingly, phytoplankton biomass estimated as chlorophyll a (chl a) is very high (annual mean for the euphotic zone: $223 \mu \mathrm{g}$ $\mathrm{l}^{-1}$ ). The lake water is alkaline and the oxygen concentration in the euphotic zone oscillates between 50 and $170 \%$ saturation. The euphotic zone is restricted to approximately $0.5 \mathrm{~m}$. The lake is currently in the process of recovery through external and internal nutrient load reductions.

Integrated water samples of the euphotic zone were collected with a 51 Schindler-Patalas sampler (length: $0.5 \mathrm{~m}$ ) at the deepest part of the lake over 1 yr at intervals of 5 to $15 \mathrm{~d}$. Analyses of the microbial food web structure, bacterial production and bacterivory have been reported in detail elsewhere (Sommaruga 1995. Sommaruga \& Psenner 1995a)

Chl a, temperature. Chl a concentrations were determined spectrophotometrically after hot ethanol extraction according to Nusch (1980). Water temperature was measured with a thermometer placed inside the sampler.

Abundance of bacteria and heterotrophic nanoflagellates. Subsamples for bacterial and nanoflagellate abundance were fixed with $37 \%$ formaldehyde at a final concentration of $2 \% \mathrm{v} / \mathrm{v}$ and stored at $4^{\circ} \mathrm{C}$ until further processing within $2 \mathrm{~d}$. Bacteria and heterotrophic nanoflagellates (HNAN) were enumerated after staining with the fluorochrome $4^{\prime}, 6^{\prime}$-diamidino-2phenylindole (DAPI) on black membrane filters (Poretics $0.2 \mu \mathrm{m}$ ) by epifluorescence microscopy according to Porter \& Feig (1980). On 1 occasion (January 21) we took triplicate samples in order to determine the variability of the total bacterial counts and of the active fraction (see below). The coefficient of variation among replicates for both parameiers was $\leq 9 \%$.

Abundance of metabolically active bacteria. The tetrazolium salt 2-( $p$-iodophenyl)-3-( $p$-nitrophenyl)-5phenyltetrazolium chloride (INT, Sigma) was used as an indicator of the activity of the electron transport system in respiring cells (Zimmermann et al. 1978, Dufour \& Colon 1992). A $10 \mathrm{ml}$ volume of lake water was incubated with INT at a final concentration of $0.02 \% \mathrm{w} / \mathrm{v}$ in the dark at in situ temperature (Dufour \& Colon 1992). We did not conduct a time-course experiment of INT labeling but incubated the samples for $1 \mathrm{~h}$ as suggested by Dufour et al. (1990). Tabor \& Neihof (1984) did not find significant differences in the number of INT-reducing bacteria using incubation times of 10 min to $3 \mathrm{~h}$ at low temperatures $\left(0\right.$ to $\left.7^{\circ} \mathrm{C}\right)$. Formaldehyde-fixed controls (final conc. $2 \% \mathrm{v} / \mathrm{v}$ ) were included to account for possible non-biological reduction of INT. More than 400 INT-reducing bacteria were counted immediately after filtration onto white Millipore filters $(0.2 \mu \mathrm{m}$ pore size) at a final magnification of $\times 1250$. Glycerin was used as a mounting medium to prevent dissolution of the formazan crystals (Tabor \& Neihof 1982a). The INT method may have underestimated the abundance of active bacteria due to difficulties in detecting a formazan crystal in cells $<0.01 \mu \mathrm{m}^{3}$, which on some occasions represented up to $35 \%$ of the bacterial assemblage. However, as discussed by Sommaruga \& Psenner (1995a) not all DAPI-stained particles of this size were bacteria, i.e. some may have been viruses.

Bacterial activity and bacterivory experiments. The $\left[{ }^{14} \mathrm{C}\right]$-leucine method (Kirchman et al. 1985, Simon \& Azam 1989) was used to estimate bacterial activity. $\left[{ }^{14} \mathrm{C}\right.$ leucine (Amersham, $310 \mathrm{mCi} \mathrm{mmol}^{-1}$ ) was added to 3 vials containing $10 \mathrm{ml}$ of lake water at a final concentration of $20 \mathrm{nM}$ and incubated in the dark for $1 \mathrm{~h}$. All samples were corrected for abiotic incorporation by subtracting the radioactivity in formaldehyde-killed controls ( $2 \%$ final conc. v/v). Protein was extracted in cold trichloroacetic acid (final conc. $5 \% \mathrm{v} / \mathrm{v}$ ). Filters were washed with $80 \%$ cold ethanol (Wicks \& Robarts 1988). 
The amount of leucine incorporated was calculated using the formula of Simon \& Azam (1989), assuming a 2-fold intracellular dilution.

Grazing by HNAN was estimated on 18 of the 36 sampling dates using short-term uptake experiments of fluorescently labeled bacteria (FLB) as prey surrogates (Sherr \& Sherr 1993). The FLB had a mean length $( \pm \mathrm{SD})$ of $0.96 \pm 0.34 \mu \mathrm{m}$ and a mean width of $0.4 \pm 0.1 \mu \mathrm{m}$ with an equivalent mean

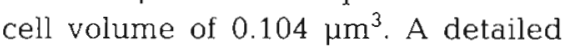
description of FLB preparation and experimental protocol is found in Sommaruga (1995).
Table 1. Summary of descriptive statistics for environmental conditions and relevant biological parameters in the euphotic zone of Lake Rodó (Uruguay) Values represent means and range for 1 yr $(n=36)$

\begin{tabular}{|c|c|c|c|}
\hline Parameter & Mean & Minimum & Maximum \\
\hline Chlorophyll a $\left(\mu \mathrm{g} \mathrm{l}^{-1}\right)$ & 223 & 99 & 335 \\
\hline Temperature $\left({ }^{\circ} \mathrm{C}\right)$ & 18.9 & 8.2 & 28.0 \\
\hline Total bacteria $\left(10^{6}\right.$ cells $\left.\mathrm{ml}^{-1}\right)$ & 6.96 & 1.51 & 20.4 \\
\hline Active bacteria $\left(10^{6}\right.$ cells $\left.\mathrm{ml}^{-1}\right)$ & 2.95 & 0.43 & 604 \\
\hline Proportion of active bacteria (\%) & 46.8 & 16.5 & 100 \\
\hline Bacterial activity (nmol Leu $\mathrm{l}^{-1} \mathrm{~h}^{-1}$ ) & 7.91 & 0.97 & 14.5 \\
\hline Bact. specific activity (fmol Leu cell ${ }^{-1} \mathrm{~h}^{-1}$ ) & 0.0028 & 0.0009 & 0.0054 \\
\hline Bact. specific activity ${ }^{b}$ (fmol Leu cell ${ }^{-1} \mathrm{~h}^{-1}$ ) & 0.0013 & 0.0007 & 0.0034 \\
\hline Heterotrophic nanoflagellates $\left(10^{3}\right.$ cells $\left.\mathrm{ml}^{-1}\right)$ & 11.9 & 1.1 & 29.5 \\
\hline Community uptake rate $\left(10^{3}\right.$ bact. $\left.\mathrm{ml}^{-1} \mathrm{~h}^{-1}\right)$ & 776 & 82 & 2145 \\
\hline
\end{tabular}

\section{RESULTS}

\section{Abundance and proportion of metabolically active bacteria}

The abundance of both total and metabolically active bacteria changed over the year by 14 -fold (Table 1 ). Total bacterial abundance ranged from $1.51 \times 10^{6} \mathrm{ml}^{-1}$ in winter (June) to $20.4 \times 10^{6} \mathrm{ml}^{-1}$ in summer (February) (Fig. 1A). The abundance of metabolically active bacteria was also lowest in winter $(0.43 \times$ $10^{6} \mathrm{ml}^{-1}$ ) while the maximum was found at the beginning of autumn $\left(6.04 \times 10^{6} \mathrm{ml}^{-1}\right)$ when temperatures were still high $\left(22.0^{\circ} \mathrm{C}\right)$. The abundance of metabolically active bacteria was positively correlated with the total bacterial abundance $(r=0.736, p<0.001$; Fig. 2, Table 2). The annual average proportion of active bacteria was $46.8 \%$ and varied from $16.5 \%$ in winter to $100 \%$ in March (Fig. 1B). The proportion of active bacteria tended to covary inversely with total bacterial abundance, especially during the first part of the study (Fig. 1). However, this trend was not statistically significant, and the proportion of active bacteria reached low values at different times of the year. For example, similar values of ca $20 \%$ were observed in summer (at the time of maximum total bacterial abundance) and in winter (Fig. 1B). The maximum percentage of active bacteria was coincident with a sudden decrease in the abundance of HNAN from 29500 to 7900 cells $\mathrm{ml}^{-1}$ (data not shown).

The planktonic bacterial assemblage of Lake Rodó is characterized by the permanent presence of filamentous bacteria up to $210 \mu \mathrm{m}$ long. We do not have data about cell size distribution of metabolically active bacteria but observed that all filamentous bacteria inspected were metabolically active and usually contained several red formazan spots. Non-filamentous active bacteria (rods of 0.5 to $1 \mu \mathrm{m}$ length) were usually found associated with filamentous bacteria. We also observed on several occasions filaments of Plankto-
Fig. 1. Seasonal variability of (A) total bacterial abundance and (B) proportion of active (INT-reducing bacteria) and inactive bacteria in the euphotic zone of Lake Rodó (Uruguay)

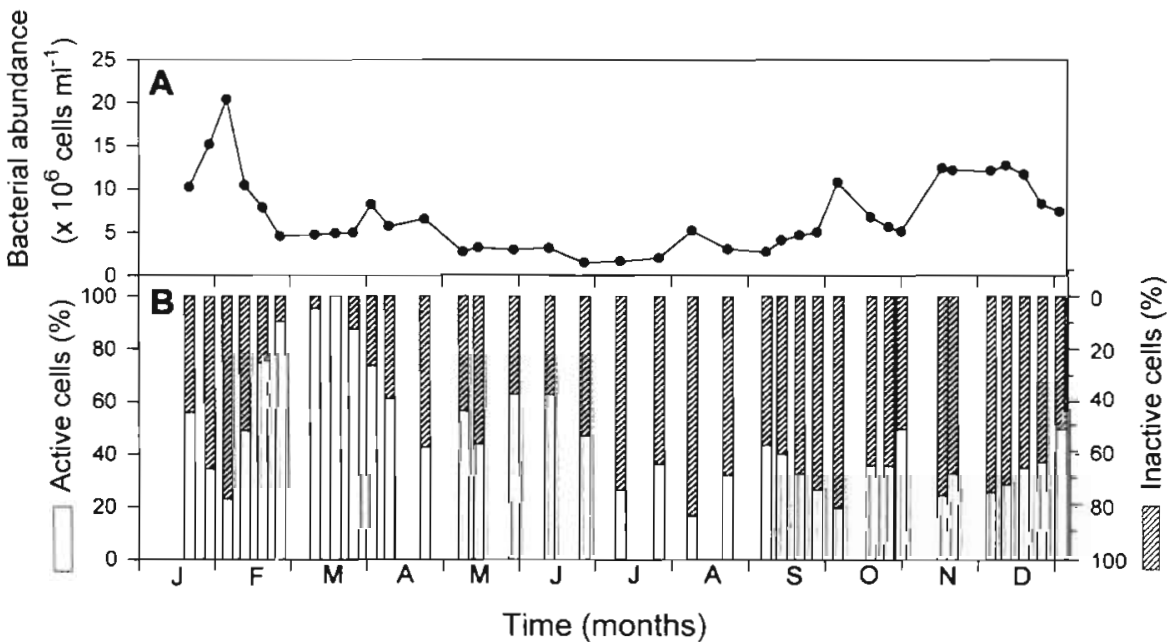


Table 2. Matrix of Pearson correlations for total bacterial abundance (Tot), abundance of metabolically active bacteria (Act), chlorophyll a concentration ( $\mathrm{Chl}$ a), abundance of heterotrophic nanotlagellates (HNAN), temperature (Temp) and $\left[{ }^{14} \mathrm{C}\right]$-leucine uptake (Leu). Number of observations: $\mathrm{n}=36$. $\cdot p<0.05, \cdots p<0.001$; ns: not significant. All data except temperature were $\log _{10}$ transformed

\begin{tabular}{|c|c|c|c|c|c|}
\hline & Act & Chl a & HNAN & Temp & Leu \\
\hline Tot & $0.736^{\cdots}$ & $0.560^{\cdots}$ & $0.587^{\cdots}$ & $0.744^{\cdots}$ & $0.701^{\circ}$ \\
\hline Act & & $0.338^{\circ}$ & $0.734 \cdots$ & $0.897^{\cdots}$ & $0.825^{\circ}$ \\
\hline Chl a & & & ns & $0.360^{\circ}$ & $0.396^{\circ}$ \\
\hline HNAN & & & & $0.698^{\circ}$ & $0.713^{\circ}$ \\
\hline Leu & & & & & 0.904 " \\
\hline
\end{tabular}

thrix agardhii with bacteria adhered to the sheath These bacteria were characteristically long $(1.5 \mu \mathrm{m})$, metabolically active rods. However, $<10 \%$ of the filaments of $P$. agardhii inspected had adhered bacteria. Most bacteria (>90\%) in the euphotic zone were freeliving

\section{Parameters related to the abundance of active bacteria}

Water temperature in the first $0.5 \mathrm{~m}$ of the water column varied by $19.8^{\circ} \mathrm{C}$ (Table 1) during the year and had a major positive effect on the abundance of active bacteria (Fig. 3). Temperature was more highly correlated with the abundance of metabolically active bacteria $(r=0.897, p<0.001)$ than with total bacterial abundance $(r=0.744, p<0.001$; Table 2$)$. The concentration of chl $a$, which ranged from 99 to $335 \mathrm{\mu g} \mathrm{l}^{-1}$, was weakly correlated with the abundance of active bacte-

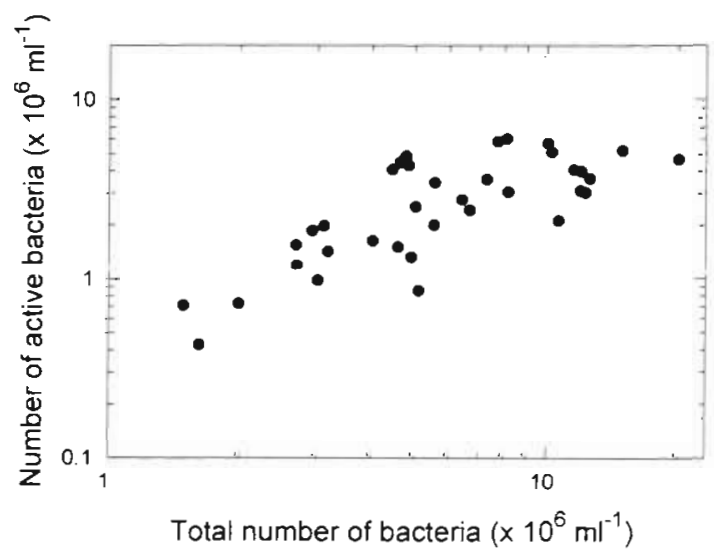

Fig. 2. Log-log relationship between the abundance of metabolically active bacteria and total bacterial abundance in the euphotic zone of Lake Rodó ria $(r=0.338, p<0.05)$. The abundance of HNAN, the main consumers of bacteria in this lake (Sommaruga 1995). was positively correlated with total bacterial abundance $(r=0.587, p<0.001$ ) but the correlation was higher with the abundance of active bacteria ( $\mathrm{r}=$ $0.734, p<0.001)$. Also, the flagellate community uptake rate was significantly correlated with the abundance of active bacteria ( $r=0.693, p<0.01, n=18$; Fig. 4B) although the correlation was stronger with total bacterial abundance $(\mathrm{r}=0.819, \mathrm{p}<0.001, \mathrm{n}=18)$.

The proportion of metabolically active bacteria was not significantly correlated to any of the parameters mentioned above, although, as noted before, there was a trend for them to decrease when total numbers increased (Fig. 1). Bacterial activity $\left(\left[{ }^{14} \mathrm{C}\right]\right.$-leucine uptake) was also better correldited with the abundarice of active bacteria than with total bacterial abundance (Fig. 5, Table 2). Mean cell-specific activity (bacterial activity/bacterial abundance; Table 1) was significantly greater ( $t$-test, $\mathrm{p}<0.001$ ) for active cell numbers when compared to total cell numbers.

\section{DISCUSSION}

\section{Proportion and abundance of metabolically active bacteria}

This study deals with the seasonal variability of metabolically active bacteria in the euphotic zone of a hypertrophic lake and the main factors associated with their variation. The question whether bacterioplankton is predominantly composed of active or inactive (dormant) cells has important implications for the understanding of bacteria-mediated processes on a cell-

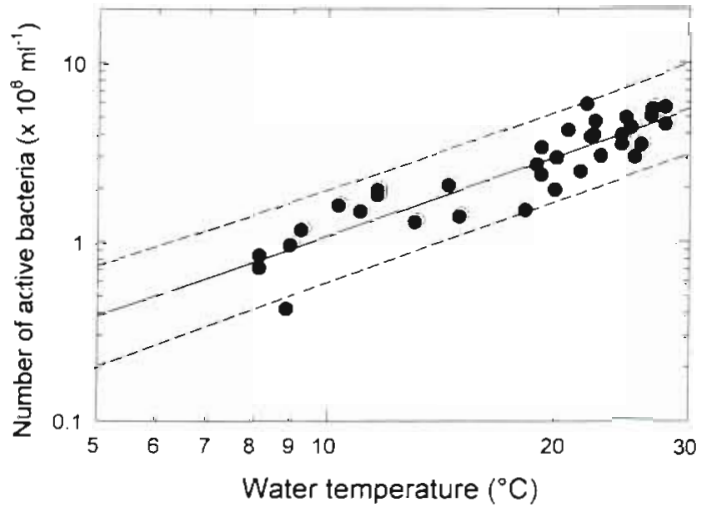

Fig. 3. Relationship between the abundance of metabolically active bacteria (Act) and water temperature (Temp) in the euphotic zone. The regression line (solid line) represents the linear least square fit of log Act vs Temp. Dashed lines represent the $95 \%$ prediction intervals 
specific basis. In this study, active bacterioplankton was determined by assays based on the reduction of the tetrazolium salt INT. We emphasize, however, that at present there is no general agreement on a standard method to estimate the abundance of active bacteria. Therefore, comparisons with results from studies using other methods of estimating their abundance should be considered with caution. For instance, results from a recent study suggest that the CTC dye may have an inhibitory effect on aquatic bacteria (Ullrich et al. 1996). Nevertheless, our results and those from others (Zimmermann et al. 1978, Tabor \& Neihof 1984, Dufour et al. 1990, del Giorgio \& Scarborough 1995, Karner \& Fuhrman 1997) indicate that despite different methodologies not all bacteria stained with DAPI or acridine orange and counted under an epifluorescence microscope are active.

The annual average proportion of active bacteria in Lake Rodó $(-47 \%)$ was higher than the average for freshwater lakes (23\%, literature data) of lower trophic state reported by del Giorgio \& Scarborough (1995). Information on the proportion of active bacteria from other hypertrophic systems is only available for the
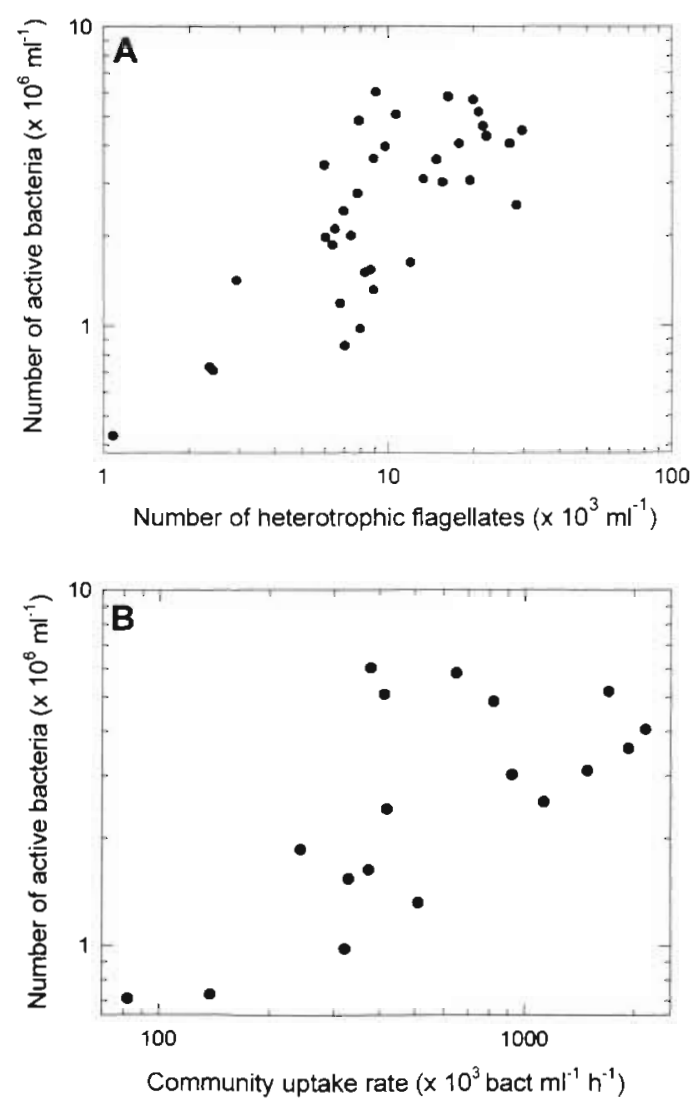

Fig. 4. Log-log relationships between the abundance of metabolically active bacteria and (A) the abundance of heterotrophic nanoflagellates and (B) their total uptake rate reservoir Hartbeespoort Dam, South Africa. Phytoplankton of this warm-water system was dominated by the cyanobacterium Microcystis aeruginosa, which reached chl a concentrations of up to $6530 \mathrm{\mu g} \mathrm{l}^{-1}$ and attained primary production rates which were the highest ever reported for aquatic systems (Robarts \& Wicks 1990). Surprisingly, the maximum percentage of active bacteria estimated by the nalidixic method was only $48 \%$ (Robarts \& Sephton 1988). However, whether the low percentage in Hartbeespoort Dam was a consequence of an underestimation of the number of active bacteria by the nalidixic method, as suggested by the results from Tabor \& Neihof (1984), is not known. Maki \& Remsen (1981) did not find any significant difference between that method and the INTreduction method. Alternatively, there is evidence that in Hartbeespoort Dam, despite high bulk concentrations of dissolved organic carbon, bacterial growth was limited by the availability of labile dissolved organic carbon (Robarts \& Wicks 1990).

In Lake Rodó, the rapid bacterial turnover times which ranged from 5 to $42 \mathrm{~h}$ (Sommaruga 1995) contrasted with the fact that, with the exception of the period between February 26 and March 26 (>85\% of active bacteria), the proportion of inactive bacteria was always significant. Notwithstanding methodological constraints of the INT method like, for example, the low sensitivity for detecting under the optical microscope a formazan crystal inside very small bacterial cells or those with low respiration rates, other factors may have contributed to the underestimation of the proportion of active bacteria. One such factor may have been that total bacterial abundance was overestimated. Zweifel \& Hagström (1995), using a method to eliminate nonspecific binding of DAPI to DNA, have shown that only 2 to $32 \%$ of the bacterioplankton from different marine systems appeared to contain nucleoids (condensed DNA in the bacterial

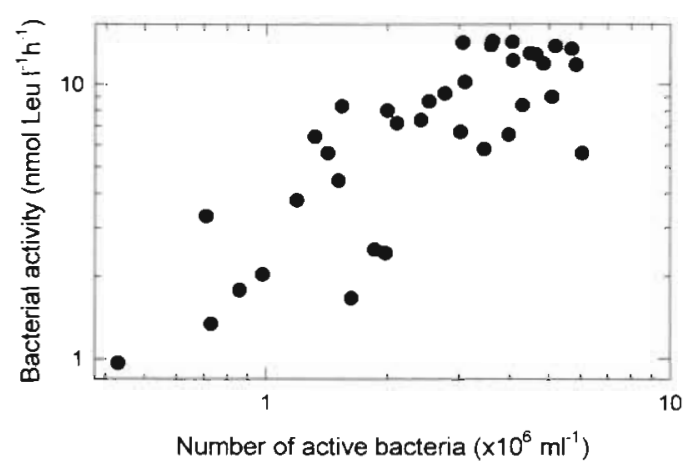

Fig. 5. Log-log relationship between the abundance of metabolically active bacteria and bacterial activity $\left[\left[{ }^{14} \mathrm{C}\right]\right.$-leucine incorporation) in the euphotic zone 
cell). They suggested that the remaining DAPIstained particles were nonliving cells, probably viruslysed bacteria or remains of protozoan grazing. The results of Zweifel \& Hagström (1995) are important because if found to be a common feature in aquatic systems then estimations of the percentage of metabolically active bacteria will be higher. Recently, Choi et al. (1996) also found that in Oregon (USA) coastal waters only 21 to $64 \%$ of bacteria had visible nucleoids. However, they observed that cells without visible nucleoids developed nucleoids when supplied with nutrients and proposed that these cells were not devoid of DNA. Choi et al. (1996) also observed that the abundance of metabolically active bacteria was lower than the number of cells with visible nucleoids except during the log-phase growth of natural marine assemblages. The poor binding capacity of DAPI to DNA has been demonstrated to be critical for samples with salinities higher than 12\% (Zweifel \& Hagström 1995). Future studies should address the question how significant is the proportion of live, intact cells in different marine and freshwater systems. In addition, DNA-containing viruses may also be included within total direct bacterial counts with DAPI (Sommaruga et al. 1995) and contribute to the underestimation of the proportion of active bacteria.

The annual average abundance of active bacteria $\left(2.95 \times 10^{6} \mathrm{ml}^{-1}\right)$ in Lake Rodó was lower than that found in systems of lower trophy (Fig. 7A in del Giorgio \& Scarborough 1995). Beside differences in the methods used, one possible explanation is that most data presented by these authors corresponded to measurements mainly made during summer. As we have shown, both total and active bacterial abundances were much higher during summer (Fig. 1). Yet, if we consider only the summer data, then the average for total and active bacteria $\left(11.7 \times 10^{6}\right.$ and $4.24 \times 10^{6} \mathrm{ml}^{-1}$, respectively) ranged among the highest values in the regression data presented by del Giorgio \& Scarborough (1995). However, mean summer densities of active bacteria in Lake Rodó were still $\sim 65 \%$ lower than, for example, in Chesapeake Bay (INT method) with similar water temperatures (Tabor \& Neihof 1984). This suggests that the abundance of active bacteria may not increase as rapidly as phytoplankton biomass does along the trophic gradient. More studies in aquatic systems with chl a concentrations $>50 \mu \mathrm{g} \mathrm{l}^{-1}$ are necessary before the relationship established by del Giorgio \& Scarborough (1995) can be generalized. As suggested by Bird \& Kalff (1984) and supported by a recent review of the literature on hypertrophic systems (Sommaruga \& Robarts in press), total bacterial numbers do not increase at the same rate as phytoplankton biomass with increasing trophy.

\section{Variables related to the seasonal variability of the abundance of metabolically active bacteria}

The high water temperature, high nutrient concentrations and phytoplankton biomass probably interact in Lake Rodó to explain the high proportion and abundance of active bacteria at certain times of the year. Temperature is an important environmental parameter known to affect bacterial growth and respiration, and abundance of active bacteria (Tabor \& Neihof 1984, Packard 1985, Robarts \& Sephton 1988). In this study, the seasonal abundance of metabolically active bacteria was strongly dependent on water temperature. The variability explained by temperature ( $81 \%$ ) was 2.1 times higher than that found in the warm but deeper Hartbeespoort Dam (Robarts \& Sephton 1988). Temperature had also a major effect on bacterial activity ([14 C]-leucine uptake) in Lake Rodó (Sommaruga 1995) with a $Q_{10}$ value of 3.1, well within the range of values reported for general microbial processes.

The range in which water temperature changes may also be important in determining the magnitude of seasonal variability in the abundance of active bacteria. Simek et al. (1990) found in the mesotrophic Rímov reservoir (Czech Republic) during springautumn, when temperature changed by $20.6^{\circ} \mathrm{C}$, a smaller change in the abundance of total bacteria (3fold) than in the active fraction (11-fold) as determined by autoradiography. In the mesotrophic Piburger See (Austria), Sattler (1992) also found that total bacterial abundance at the surface changed from spring to winter (temperature change $=22.6^{\circ} \mathrm{C}$ ) by only 3.8 -fold $\left(1.16\right.$ to $\left.4.41 \times 10^{6} \mathrm{ml}^{-1}\right)$ but that the abundance of active bacteria (INT method) changed by 2 orders of magnitude $\left(1.07 \times 10^{4}\right.$ to $2.25 \times$ $10^{6} \mathrm{ml}^{-1}$ ). In contrast, our results show that total bacterial abundance and the number of active bacteria both changed over the year by more than an order of magnitude. This agrees with the results from Hartbeespoort Dam (temperature range $=12$ to $26^{\circ} \mathrm{C}$ ), where both total and active bacterial abundances changed by about 9-fold (Robarts \& Sephton 1988). We hypothesize that the different patterns observed among these systems may be related to the range in which temperature changes and how cell activity is affected. Thus, while in Piburger See, Rimov reservoir and Lake Rodó the absolute change in water temperature was similar, the minimum temperatures registered during the study period were $0.45,2$ and $8^{\circ} \mathrm{C}$, respectively. The increase of water temperature from very low values probably has a strong positive effect on the abundance of metabolically active bacteria, providing that other factors like nutrient availability are not limiting. 
The fact that in Lake Rodó the abundance of active bacteria was weakly correlated with chl a $(r=0.355)$ may be an indication that in hypertrophic systems other sources of dissolved organic carbon beside phytoplankton, e.g. organic pollution, may be quantitatively more important. This is supported by the results from Robarts \& Sephton (1988) who found that primary production of particulate and dissolved organic carbon in the hypertrophic Hartbeespoort Dam explained only 22 and $14 \%$, respectively, of the annual variability in the abundance of active bacteria at the surface.

One important factor controlling how long a bacterial cell remains in the active bacterial fraction is its loss rate, mainly by grazing or cell lysis (del Giorgio \& Scarborough 1995). Recent evidence suggests that HNAN remove the active fraction rather than non-selectively grazing the entire bacterial standing stock (Gasol et al. 1995, del Giorgio et al. 1996). Whether HNAN grazed preferentially on active bacteria because they were larger than others cannot be assessed from our results. Interestingly, we found that the abundance of HNAN, the main bacterial grazers in this lake (Sommaruga 1995), was better correlated with the abundance of active bacteria than with total bacterial abundance. However, due to the autocorrelation of the abundance of active bacteria and HNAN with temperature it is difficult to establish the real direction of this relation. In addition, the fact that the maximum proportion of active bacteria in March was coincident with a drastic drop in the abundance of HNAN (Sommaruga 1995) suggests that HNAN may be important for the control of the active fraction.

Finally, although as discussed above no standard method of differentiating the active bacterial fraction exists, the closer relation of bacterial activity to the abundance of the active fraction than to total bacterial numbers in Lake Rodó suggests that using the active fraction gives a better meaning to calculations like cell-specific activity or generation times as indicated previously (Dufour et al. 1990, del Giorgio \& Scarborough 1995, Sommaruga \& Psenner 1995b, Pernthaler et al. 1996). Whereas bacteria with very low respiration rates might not produce detectable formazan crystals during the incubation period with INT, these bacteria probably may not contribute significantly to the total metabolic activity of bacterial assemblages (Dufour et al. 1990).

Acknowledgements. We thank R. Robarts, R. Psenner, T. Posch, A. Alfreider and S. Andreata for improving the clarity of the manuscript, Ma. L. Arín for technical assistance and 3 anonymous reviewers for critical comments. This work was supported by research grants from CSIC (Universidad de la República, Uruguay) and the North-South Dialogue Programme (Austria) to R.S.

\section{LITERATURE CITED}

Bird DF, Kalff J (1984) Empirical relationships between bacterial abundance and chlorophyll concentration in fresh and marine waters. Can J Fish Aquat Sci 41:1015-1023

Choi JW, Sherr EB, Sherr BF (1996) Relation between presence-absence of a visible nucleoid and metabolic activity in bacterioplankton cells. Limnol Oceanogr 41:1161-1168

Cole JJ, Findlay S, Pace MI (1988) Bacterial production in fresh and saltwater ecosystems: a cross-system overview. Mar Ecol Prog Ser 43:1-10

del Giorgio PA, Gasol JM, Vaque D, Mura P, Agusti S, Duarte CM (1996) Bacterioplankton community structure: protist control, net production and the proportion of active bacteria in a coastal marine community. Limnol Oceanogr 41: 1169-1179

del Giorgio PA, Scarborough G (1995) Increase in the proportion of metabolically active bacteria along gradients of enrichment in freshwater and marine plankton: implications for estimates of bacterial growth and production rates. J Plankton Res 17:1905-1924.

Dufour P, Colon M (1992) The tetrazolium reduction method for assessing the viability of individual bacterial cells in aquatic environments: improvements, performance and applications. Hydrobiologia 232:211-218

Dufour P, Torreton JP, Colon M (1990) Advantages of distinguishing the active fraction in bacterioplankton assemblages: some examples. Hydrobiologia 207:295-301

Gasol JM, del Giorgio PA, Massana R, Duarte CM (1995) Active versus inactive bacteria: size-dependence in a coastal marine plankton community. Mar Ecol Prog Ser 128:91-97

Karner M. Fuhrman JA (1997) Determination of active marine bacterioplankton: a comparison of universal 16S rRNA probes, autoradiography, and nucleoid staining. Appl Environ Microbiol 63:1208-1213

Kirchman DL, K'Nees E, Hodson R (1985) Leucine incorporation and its potential as a measure of protein synthesis by bacteria in natural aquatic systems. Appl Environ Microbiol 49:599-607

Kogure K, Simidu U, Taga N (1979) A tentative direct microscopic method for counting living marine bacteria. Can J Microbiol 25:415-420

Maki JS, Remsen CC (1981) Comparison of two direct count methods for determining metabolizing bacteria in freshwater. Appl Environ Microbiol 41:1132-1138

Meyer-Reil LA (1978) Autoradiography and epifluorescence microscopy combined for the determination of number and spectrum of actively metabolizing bacteria in natural waters. Appl Environ Microbiol 36:506-512

Nusch EA (1980) Comparisons of different methods for chlorophyll and phaeopigments determination. Arch Hydrobiol Beih Ergeb Limnol 17:14-36

Packard TT (1985) Measurements of electron transport activity of microplankton. Adv Aquat Microbiol 3:207-261

Pernthaler J, Sattler B, Šmek K, Schwarzenbacher A Psenner A (1996) Top-down effects on the size-biomass distribution of a freshwater bacterioplankton community Aquat Microb Ecol 10:255-263

Porter J, Diaper J, Edwards C, Pickup R (1995) Direct measurements of natural planktonic bacterial community viability by flow cytometry. Appl Environ Microbiol 61. $2783-2786$

Porter KG, Feig YS (1980) The use of DAPI for identifying and counting aquatic microflora. Limnol Oceanogi 25:943-948

Robarts RD, Sephton LM (1988) Seasonal variations of metabolically active bacteria in a hypertrophic lake (Hartbeespoort Dam, South Africa). Hydrobiologia 160:179-188 
Robarts RD, Wicks RJ (1990) Heterotrophic bacterial production and its dependence on autotrophic production in a hypertrophic African reservoir. Can J Fish Aquat Sci 47 : $1027-1037$

Rodriguez GG, Phipps D, Ishiguro K, Ridway HF (1992) Use of a fluorescent redox probe for direct visualization of actively respiring bacteria. Appl Environ Microbiol 58:1801-1808

Sattler B (1992) Messung bakterieller Sekundärproduktion und Grazingraten mittels radiochemischer Methoden im Piburger See (Ötztal, Tirol). MSc thesis, Univ Innsbruck

Sherr EB, Sherr BF (1993) Protistan grazing rates via uptake of fluorescently labeled prey. In: Kemp PF, Sherr BF, Sherr $E B$, Cole JJ (eds) Handbook of methods in aquatic microbial ecology. Lewis Publ, Chelsea, MI, p 695-702

Simek K, Macek M, Seda J, Vyhnálek (1990) Possible food chain relationships between bacterioplankton, protozoans and cladocerans in a reservoir. Int Rev Gesamten Hydrobiol 75:583-596

Simon M, Azam F (1989) Protein content and synthesis rates of planktonic marine bacteria. Mar Ecol Prog Ser 51:201-213

Sommaruga R (1995) Microbial and classical food webs: a visit to a hypertrophic lake. FEMS Microbiol Ecol 17:257-270

Sommaruga R, Krössbacher $M$, Salvenmoser W, Catalan J, Psenner R (1995) Presence of large virus-like particles in a eutrophic reservoir. Aquat Microb Ecol 9:305-308

Sommaruga R, Psenner R (1995a) Permanent presence of grazing-resistant bacteria in a hypertrophic lake. Appl Environ Microbiol 61:3457-3459

Sommaruga R, Psenner R (1995b) Trophic interactions within the microbial food web in Piburger See (Austria). Arch Hydrobiol 132:257--278

Responsible Subject Editor: Karel Šmek, Ceské Budějovice, Czech Republic
Sommaruga R, Robarts R (in press) Minireview: the significance of autotrophic and heterotrophic picoplankton in hypertrophic ecosystems. FEMIS Microbiol Ecol

Stevenson LH (1978) A case for bacterial dormancy in aquatic systems. Microb Ecol 4:127-133

Tabor PS, Neihof RA (1982a) Improved method for determination of respiring individual microorganisms in natural waters. Appl Environ Microbiol 43:1249-1255

Tabor PS, Neihof RA (1982b) Improved microautoradiographic method to determine individual microorganisms active in substrate uptake in natural waters. Appl Environ Microbiol 44:945-953

Tabor PS, Neihof RA (1984) Direct determination of activities for microorganisms of Chesapeake Bay populations. Appl Environ Microbiol 48:1012-1019

Ullich S, Karrasch B, Hoppe HG, Jeskulke K, Mehrens M (1996) Toxic effects on bacterial metabolism of the redox dye 5-cyano-2,3-ditolyl tetrazolium chloride. Appl Environ Microbiol 62:4587-4593

Wicks RJ, Robarts RD (1988) Ethanol extraction requirement for purification of protein labeled with $\left[{ }^{3} \mathrm{H}\right\}$-leucine in aquatic bacterial production studies. Appl Environ Microbiol 54:3191-3193

Zimmermann $\mathrm{R}$, Iturriaga R, Becker-Birck J (1978) Simultaneous determination of the total number of aquatic bacteria and the number thereof involved in respiration. Appl Environ Microbiol 36:926-935

Zweifel UL, Hagström $\AA$ (1995) Total counts of marine bacteria include a large fraction of non-nucleoid-containing bacteria (ghosts). Appl Environ Microbiol 61: $2180-2185$

Manuscript received: February 2, 1997

Revised version accepted: June 13, 1997 